Ministry of Education Iraqi Directorate of Education Baghdad Karkh III

First Conference Department of Preparation and Training Division of Research and Studies

وزارة التربية العراقية مليرية تربية بغداد الكرخ الثالثة المؤتمر الاول قسم الاعلداد والتلدريب ثعبة البحوث واللدراسات

\title{
Educational competencies of mathematics teachers from their point of view in the light of variables (educational qualification, years of service, gender)
}

\author{
Haider Kazem Jasim Al-Jizani \\ Directorate of Baghdad Education Karkh III, Ministry of Education, Baghdad, Iraq \\ haiderjasim79@yahoo.com
}

\begin{abstract}
The aim of the research was to determine the extent to which teachers and teachers of mathematics have access to educational competencies from their point of view in light of the variables (qualification, experience, gender). To achieve the objectives of the research, a sample of 245 teachers was selected for sixth grade mathematics in the third Karkh education. The research tool consists of a questionnaire consisting of (50) educational competencies divided into three areas (planning, implementation, and evaluation), which have been verified and validated, and we conclude from the estimates of the teachers and teachers of mathematics (the sample of the research) on the questionnaire of educational competencies there are differences in the percentage of ownership of educational competencies Attributed to the Is scientific and years of service and sex.
\end{abstract}

\section{الكفايات التعليمية للى معلمي ومعلمات الرياضيات من وجهة نظرهم في ضوء متغيرات (المؤهل العلمي، سنوات الخدمة، الجنس)

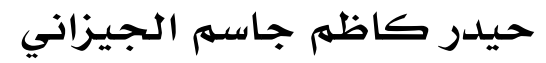 \\ وزارة التربية، المديرية العامـة للتربية بغداد في محافظة بغداد الكرخ الثالثة، بغداد، العراق haiderjasim79@yahoo.com}

المستخلص هدف البحث لمعرفة مدى امتلاك معلمي ومعلمات الرياضيات للكفايات التعليمية من وجهة نظرهم في ضوء متغيرات (المؤهل العلهي، الخبرة، الجنس ) ) ولتحقيق أهداف البحث تهم اختيار عينة

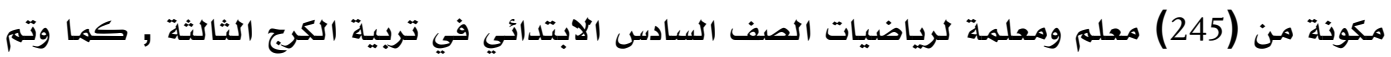

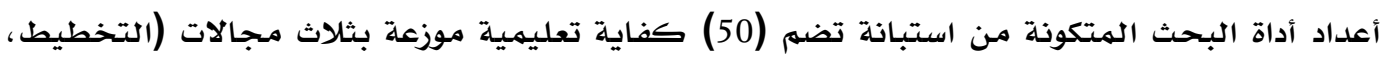
التنفيذ، التقويهم ) الذي تم التأكد من صدقها وثباتها , ونستنتج من خلال التقدئ التيرات لمعلمي ومعلمات الرياضيات (عينة البحث) حول الاستبانة للكفايات التعليمية وجود فروق في نسبة امتلاك الكفايات

$$
\text { التعليميلة تعزى للمؤهل العلمي وسنوات الخدمـة والجنس. }
$$

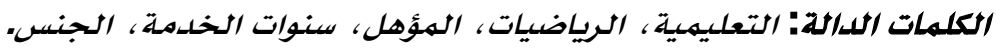

Al-Jizani, H. (2019). Educational competencies of mathematics teachers from their point of view in the light of variables (educational qualification, years of service, gender). Journal Port Science Research, 2(1), 185-202. 


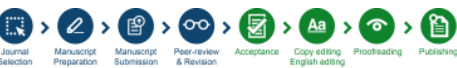

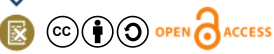

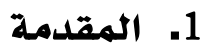

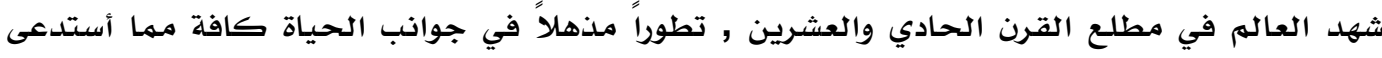

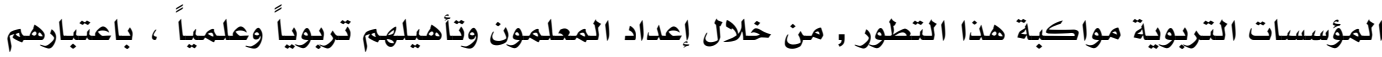

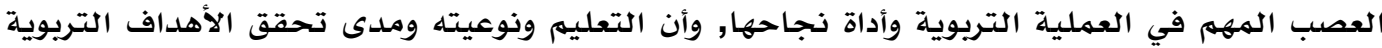

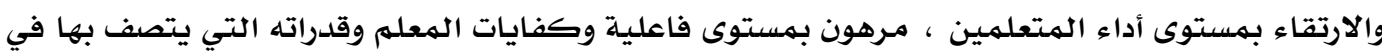
أداء رسالته ، إذ أن الدول باختلاف فلسفاتها وأهدافها تولي الارتقاء بمستوى أداء ألداء المعله جلَّ اهتمامها

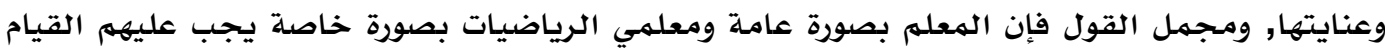

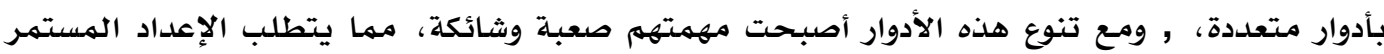

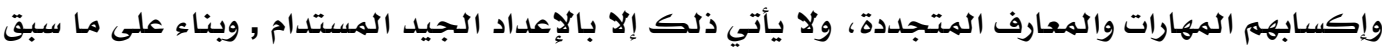

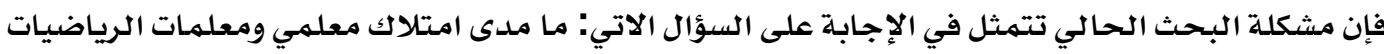

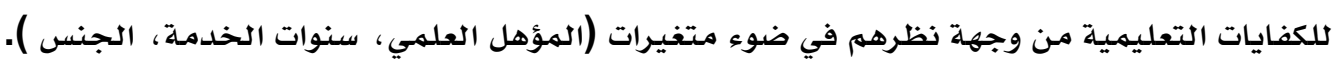

\section{(أهمية البحث}

من الركائز الأساسية للعملية التربوية (المعلم)، وحجر الزاوية والمحور الأساسي والفاعل والمؤثر في والتئي العملية التربوية والتعليمية، وإلا صلاح والتطوير والابتكار في العملية التعليمية والتربوية، عليه الترايه أن يبدأ الترأ

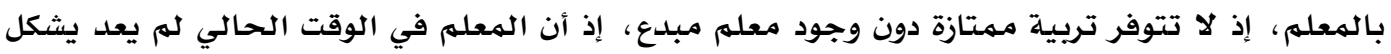

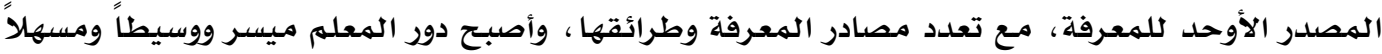

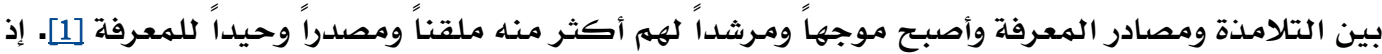

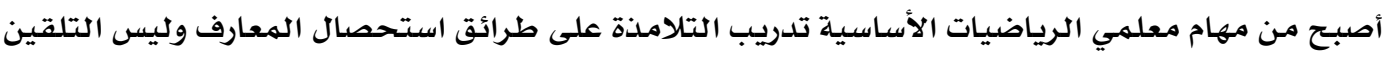

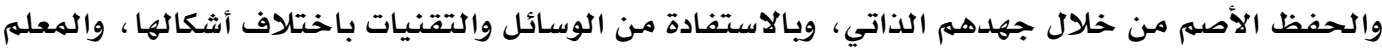

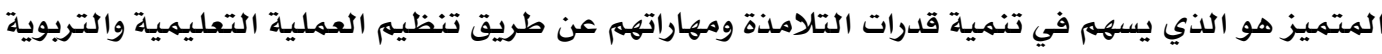

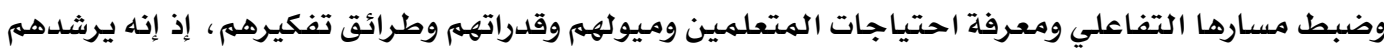

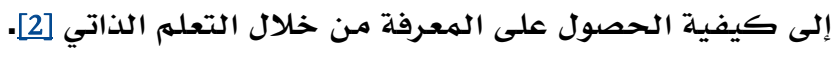

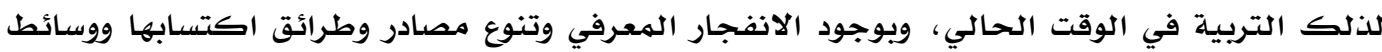

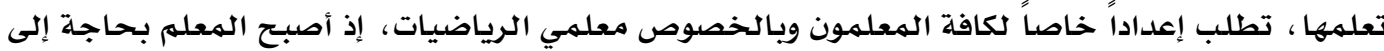

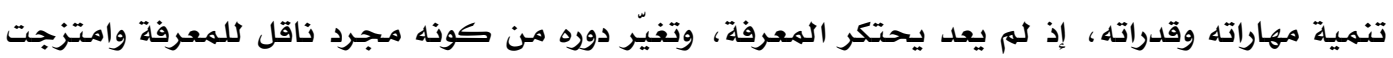

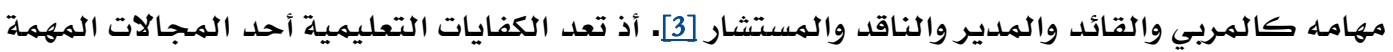

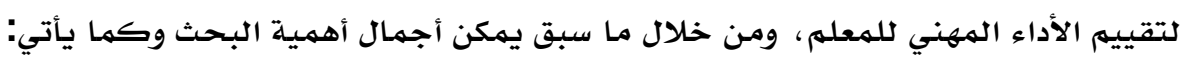

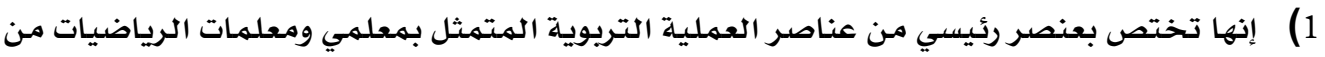

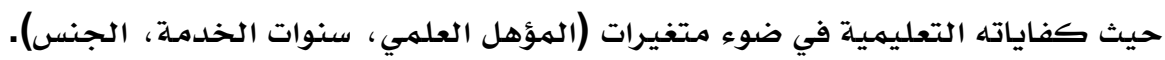

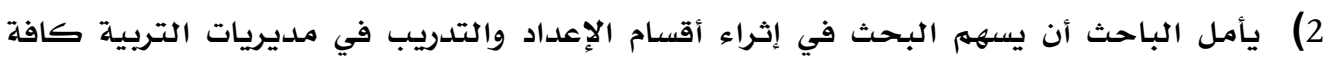

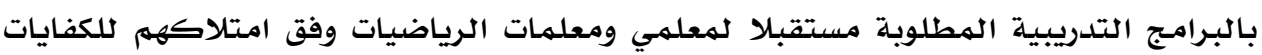

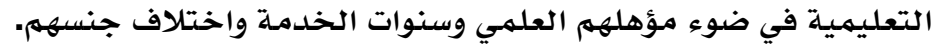

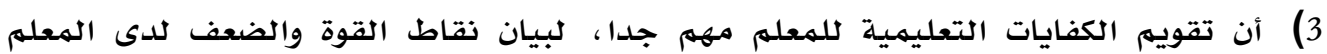

$$
\text { وانعكاساتها على العملية التربوية. }
$$

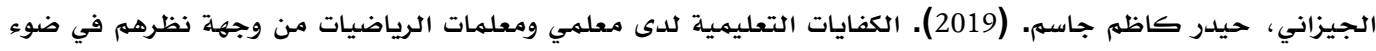
متغيرات (المؤهل العلمي، سنوات الخدمة، الجنس). Journal Port Science Research، 2 (1)، 185-202. 
يهدف البحث التعرف على الكفايات التعليمية لدى معلمي ومعلمات الرياضيات من وجهة نظرهم في ضوء الهوات البهات

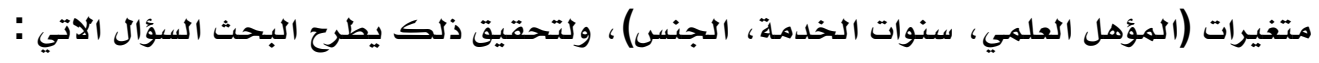

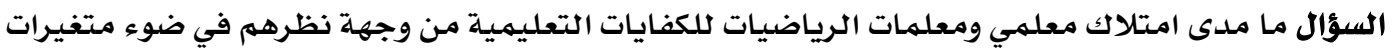

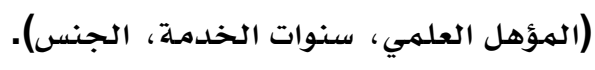

الحدود البشرية معلمي ومعلمات الرياضيات للصف السادس الابتدائي.

الحدود المكانية معلمي ومعلمات الرياضيات في مديرية تربية بغداد الديات الكرج الثالثة.

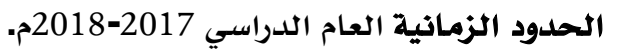

الحدود الموضومية الكفايات التعليمية المتمثلة بمجالات (التخطيط، التنفيذ، التقويم).

\section{• تحديل المصطلحصات}

الكفايات التعليمية: يعرفها (مرعي,1983) بأنها القدرة على عمل شيء أو أحداث نتاج متوقع، فهي قدرة

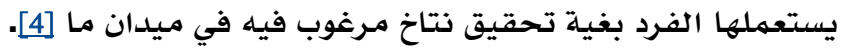

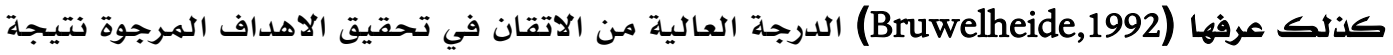

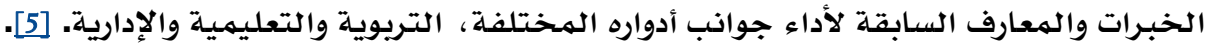

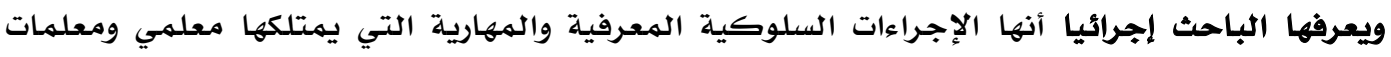
الرياضيات والتي تنعكس على قابلياتهم واستعداداتهم وفاعليتهم في التعليم داخل غرفة الصف.

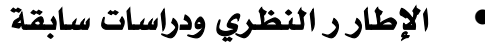

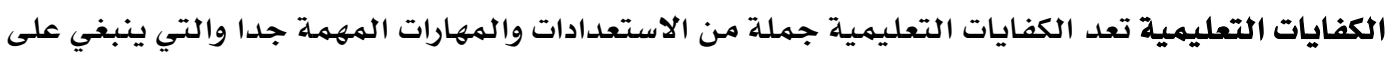

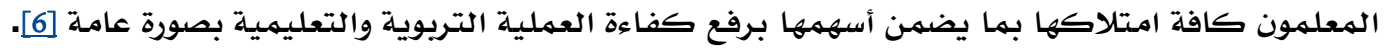

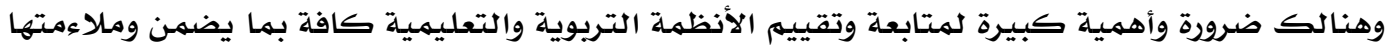

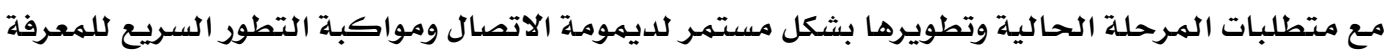

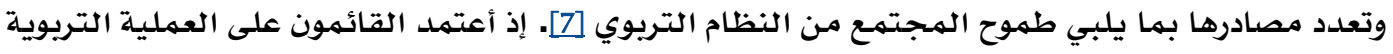

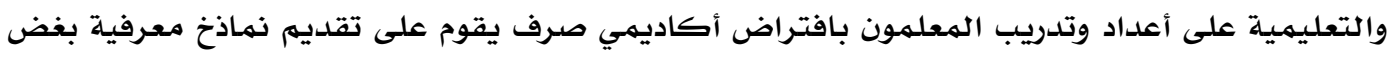

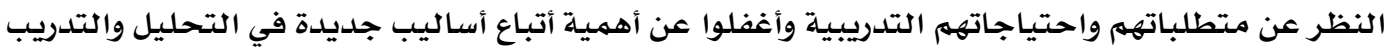

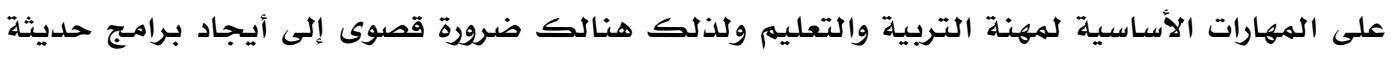

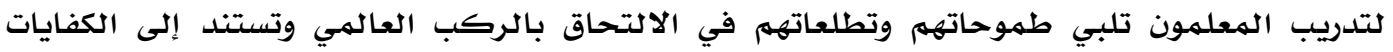

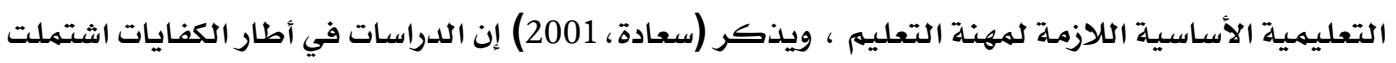

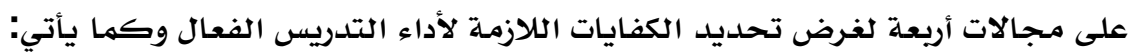

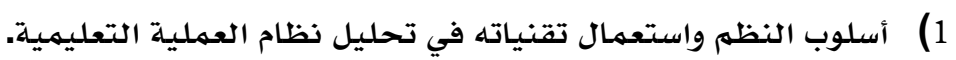
2) ملاحظة سلوك مجموعة من المعلمون المتميزون في عملية التدريس الفعال.

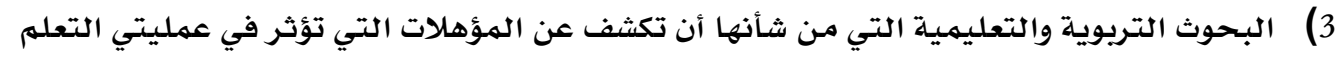

$$
\text { والتعليه بصورة ايجابية. }
$$

4) التعرف على وجهات نظر التربويين المختصين بأعداد وتأهيل المعلمين لتحديد الكفايات

التعليمية [8].

Al-Jizani, H. (2019). Educational competencies of mathematics teachers from their point of view in the light of variables (educational qualification, years of service, gender). Journal Port Science Research, 2(1), 185-202. 
وتعد الكفايات من الممارسات والأساليب التي يتقنها المعلم للقيام بواجباته التعليمية والتريوية بإلمام

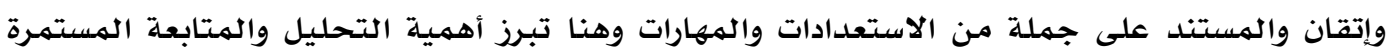

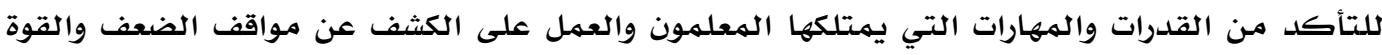

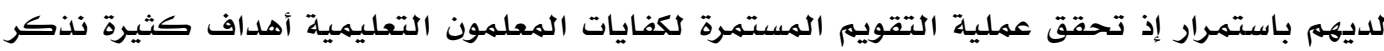

2) تقويم سلوكيات المعلمون والعمل على تعزيزها بما ينسجم ومتطلبات العملية التربوية

3) صياغة وأتباع بعض المعايير التي تساهم وتساعد المعلمون على الارتقاء بالواقع التعليمي

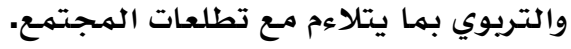

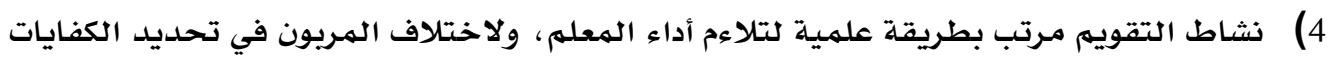

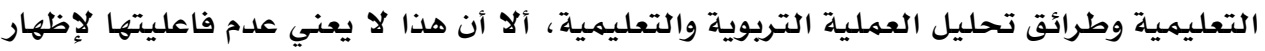

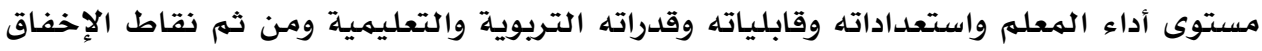

والإبداع في أساليب المعلمون وكفاياتهم [9].

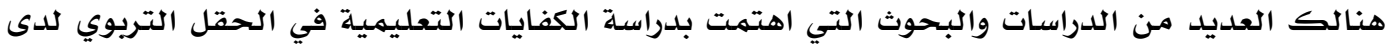

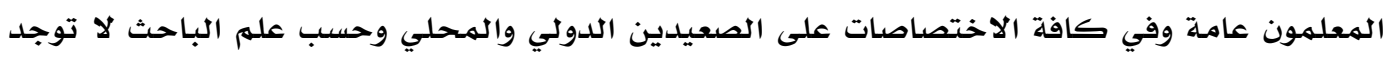

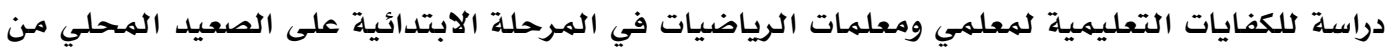

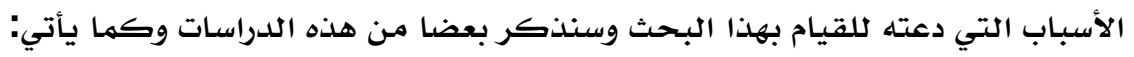

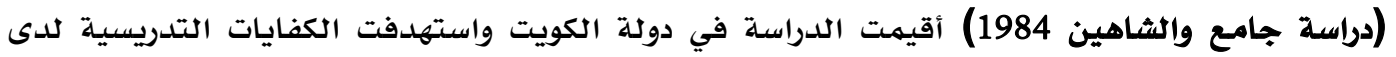

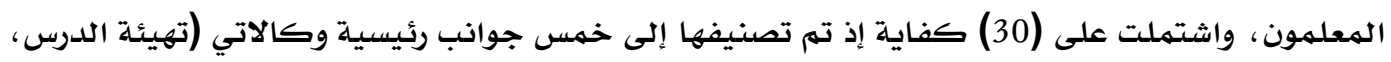

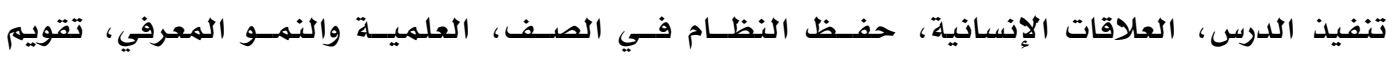

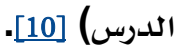
(دراسة Lewis \& Kraus وهدفت الدراسة الى معرفة الفروق بين الكفايات التدريسية لدى الطلبة الدونة

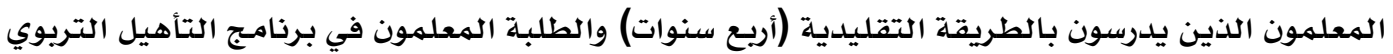

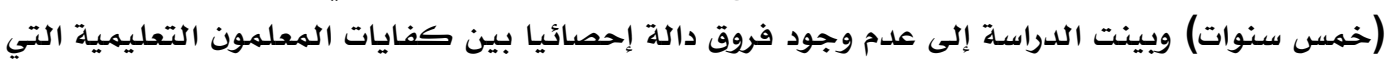

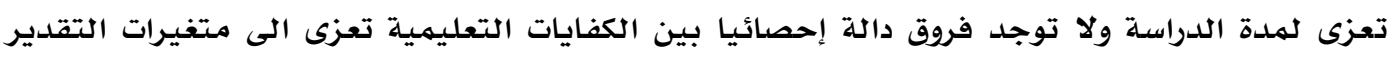

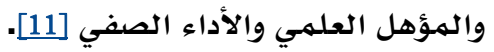

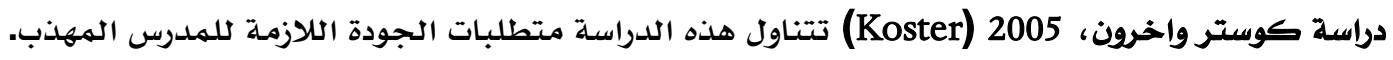

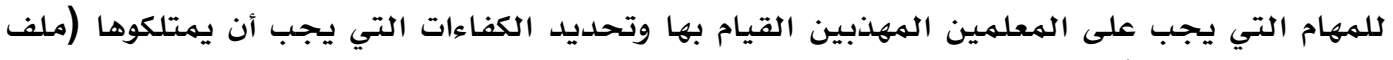

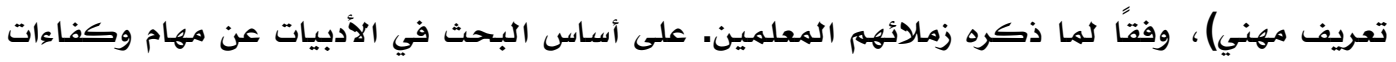

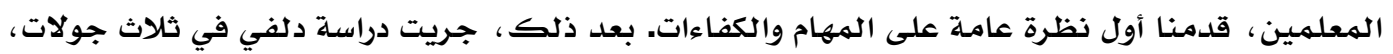

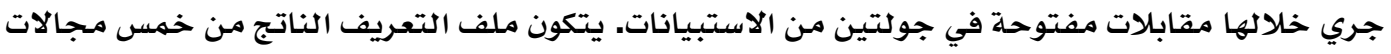

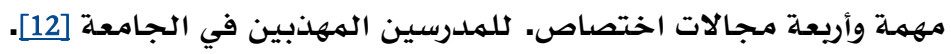

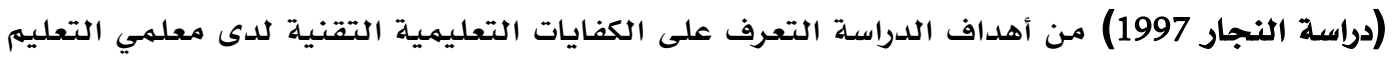

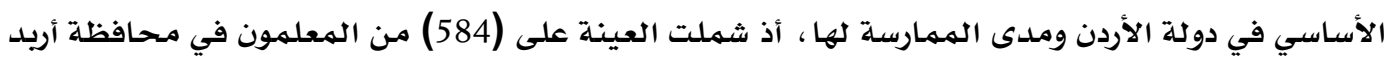

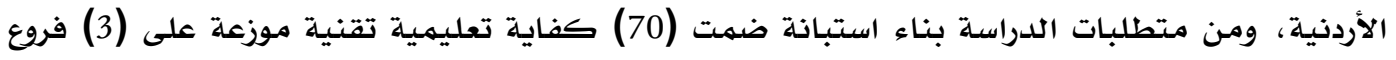

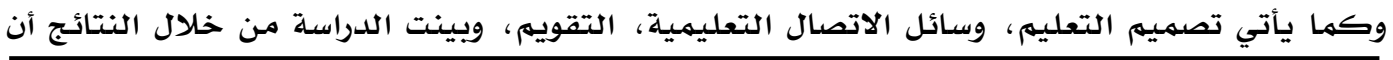
الجيزاني، حيدر كاظم جاسهم. (2019). الكفايات التعليمية لدى معلمي ومعلمات الرياضيات من وجهة نظرهم في ضوء

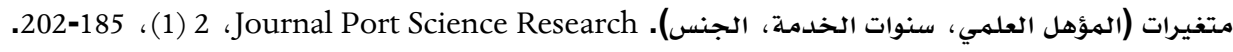


معلمون المرحلة الأساسية لديهم (62) كفاية بتقدير كبيرة و (7) فقط بتقدير متوسطة وكفاية واحدة بتقدير ضعيف [13]. دراسة تريكول واخرون 1999 (Trigwell) الدراسة التي تبين أن أساليب التدريس المختلفة من الناحية

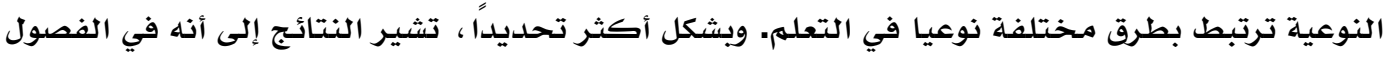

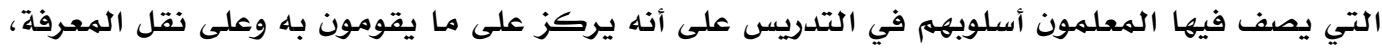

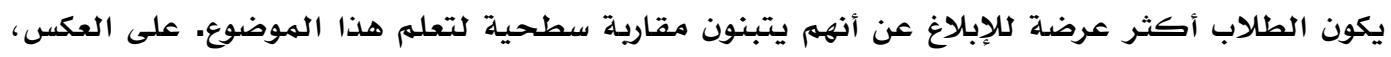

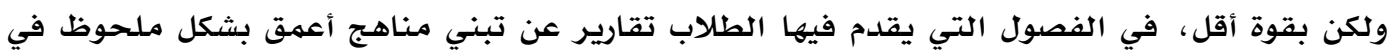

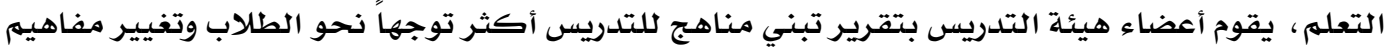

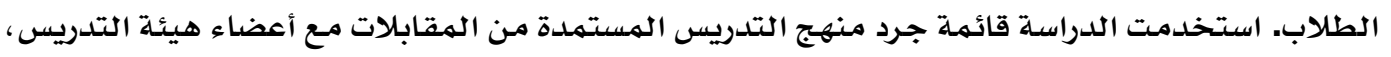

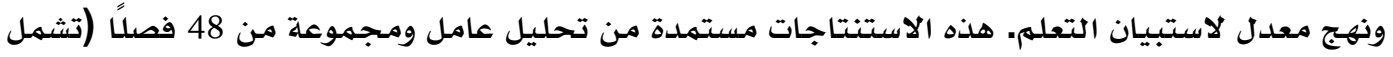

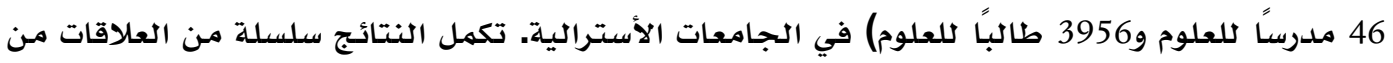

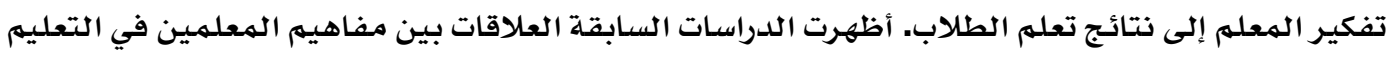

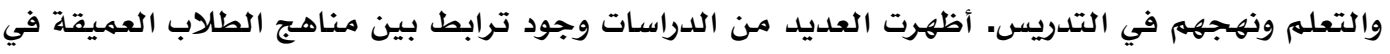

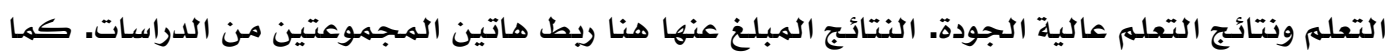
يسلطون الضوء على أهمية، في محاولات تحسين جودة تعلهم الطلاب، تثبيط التدريس في مجال النقل

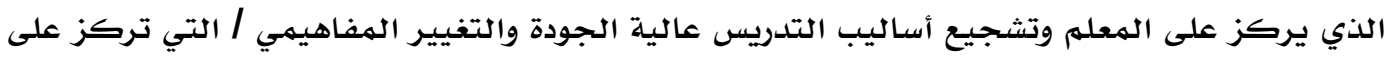

$$
\text { الطالب. [14]. }
$$

دراسة جعنيني (2000) دراسة بعنوان "الكفايات الأساسية للمعلمين في مرحلة التعليم الثانوي في الأردن

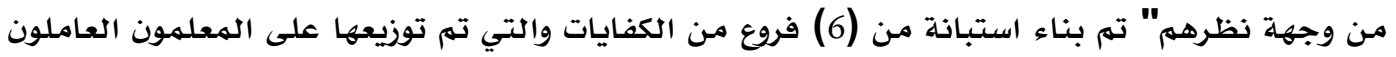

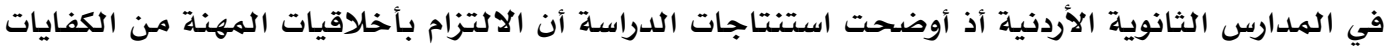

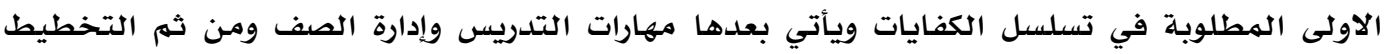

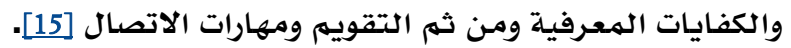

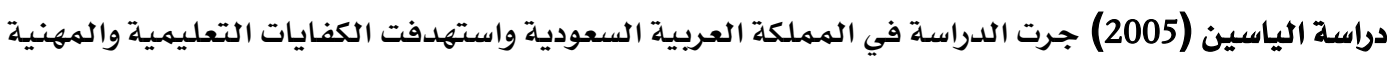

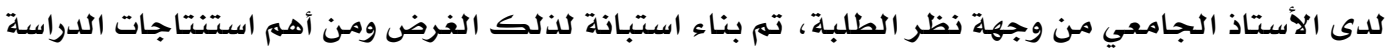

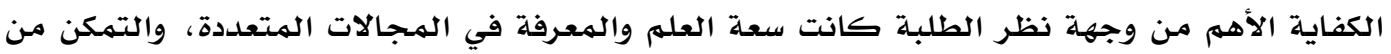
المادة التعليمية وطرائق التدريس، ومهارة ربط المادة التعليمية بالواقع الحياتي [16].

\section{2. المنهجية والإجراءات}

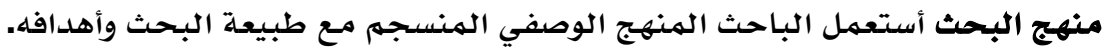

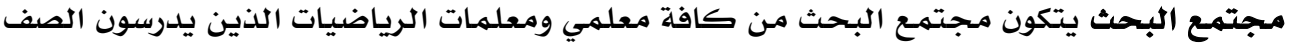

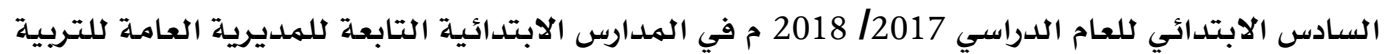
في محافظة بغداد الكرج الثالثة. عينة البحث تكونت عينة البحث من (245) معلم ومعلمة للرياضيات في الصف السادس الابتدائي والذي الذي تم اختيارهم عشوائيا من المدارس التابعة للمديرية العامـة للتربية في محافظة بغداد البهن الكرج الثالثة، وكما موضح في الجدول رقم (1).

Al-Jizani, H. (2019). Educational competencies of mathematics teachers from their point of view in the light of variables (educational qualification, years of service, gender). Journal Port Science Research, 2(1), 185-202. 

Volume: 2, No:1

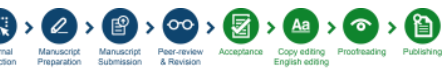

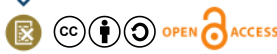

\begin{tabular}{|c|c|c|c|c|c|}
\hline \multicolumn{6}{|c|}{ جلسول (1) توزيع المعلمون في ضوء (المؤهل العلمي، سنوات الخدمة، الجنس) } \\
\hline \multirow{2}{*}{ المجموع } & \multicolumn{2}{|c|}{ بكالوريوس } & \multicolumn{2}{|c|}{ 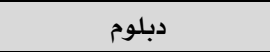 } & \multirow{2}{*}{ سنوات الخدمـة } \\
\hline & ذ ذكور & إناث & ذ ذكور & إناث & \\
\hline 123 & 32 & 28 & 28 & 35 & أقل من 10 سنوات \\
\hline 122 & 34 & 31 & 25 & 32 & 10 سنوات فما فوق \\
\hline 245 & 66 & 59 & 53 & 67 & المجمموع \\
\hline
\end{tabular}

أداة البحث قام الباحث بأعداد استبانة اشتملت على (50) فقرة من الفقرات الخاصة بالكفايات التعليمية لمعلمي ومعلمات الرياضيات للصف السادس الابتدائي، وقد تضمنت هذه الفقرات مجالات (التخطيط والتنفيذ والتقويم للتدريس).

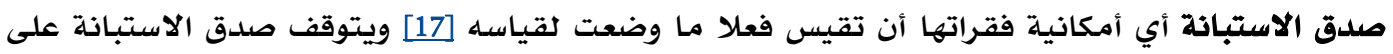

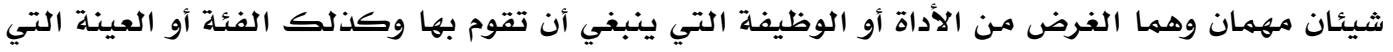

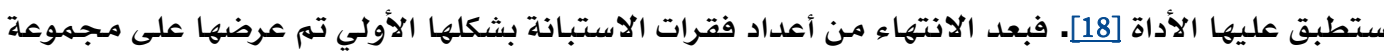

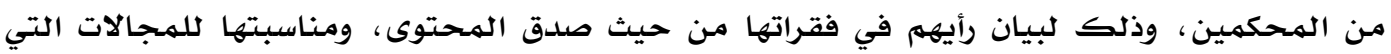

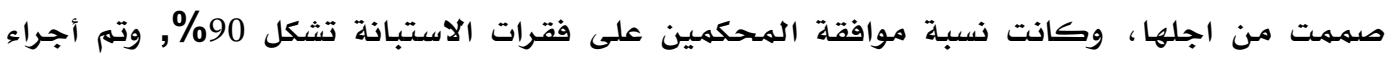

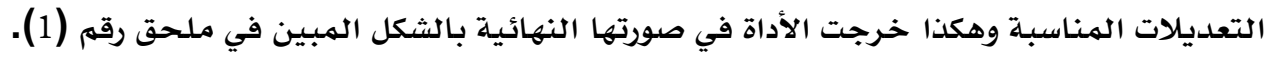

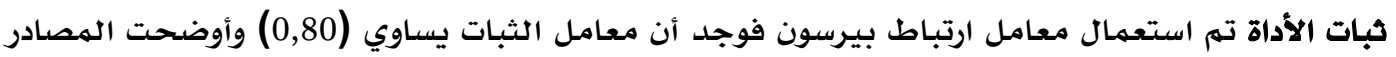

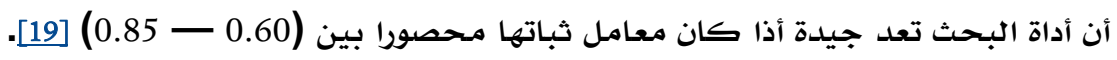

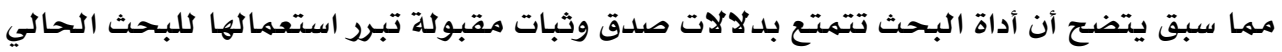

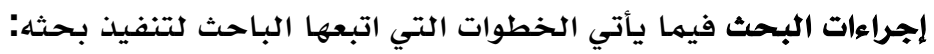

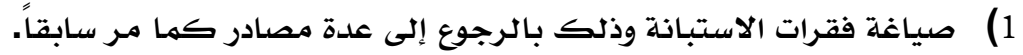

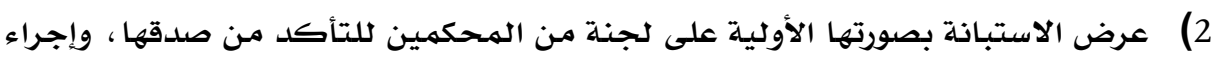
التعديلات اللازمة في ضوء آراء المحكمين واقتراحاتهم.

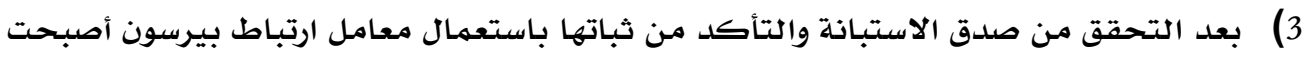
أداة البحث في صورتها النهائية جاهزة للتطبيق.

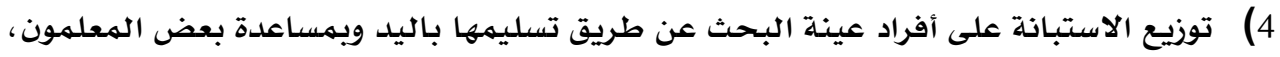
وكذلك جمع الاستبانات من أفراد العينة وتفريغ وتحليل البيانات الخاصنة باستة باستجابات أفراد العينة على الاستبانة. 5) دراسة النتائج ومناقشتها وتفسيرها ومن ثم استخلاص الاستنتاجات والتوصيات المناسبة والمقترحات.

تصحيح استجابات الأداة أستعمل الباحث في تكميم نتائج الاستبانة الخطوات الآتية:

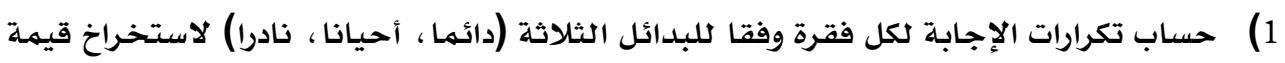
الوسط المرجح لكل فقرة في الاستبانة.

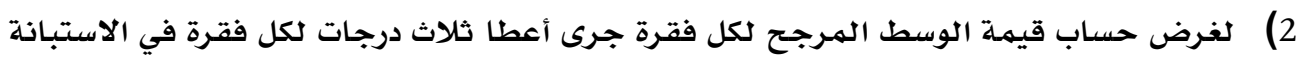

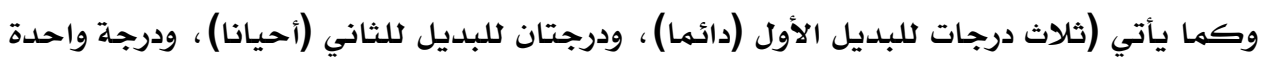

$$
\text { لبديل الثالث (نادرا). }
$$



Volume: 2, No:1

3) اعتماد متوسط درجات المقياس الثلاثي الحد الفرضي (2) معيارا للفصل بين ناحيتي القوة

والضعف للكفاية لدى المعلمون وكما يأتي:

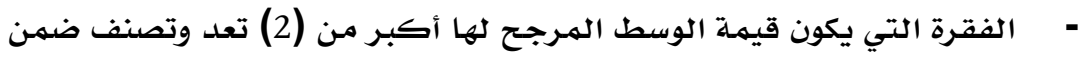

الكفايات القوية لدى المعلمون.

- الفقرة التي يكون قيمة الوسط المرجح لها أقل أو تساوي (2) تعد وتصنف ضمن

الكفايات الضعيفة لدى المعلمون.

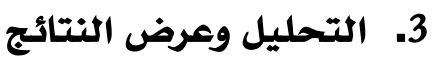

استنتاجات البحث التي تم التوصل أليها ومن ثم تفسيرها مـع بيان المقترحات والتوصيات.

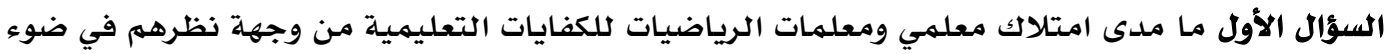

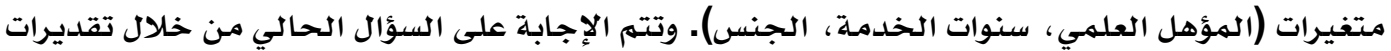

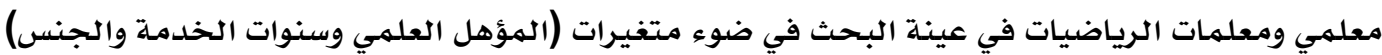

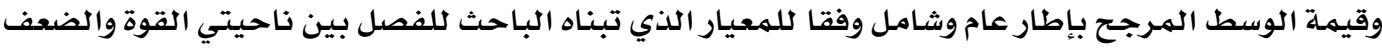

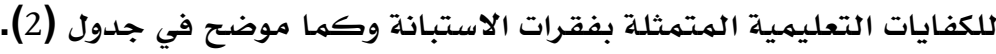

جدول رقم (2) عينة البحث في ضوء متغيرات (الهؤهل العلمي وسنوات الخدمة والجنس)

\begin{tabular}{|c|c|c|c|}
\hline تقييم الكفاية & الوسط المرجـح & الكفاية التعليمية & ت \\
\hline 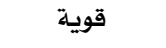 & 2.15 & اشتقاق الأهداف الخاصة والسلوكية من المحتوى التعليمي & 1 \\
\hline 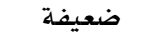 & 1.22 & لديك القدرة على تحليل المحتوى الرياضياتي & 2 \\
\hline 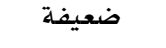 & 1.56 & تضمين الأهداف السلوكية للمستويات العليا في التفكير & 3 \\
\hline 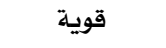 & 2.31 & استعمال الوسائل التعليمية والأنشطة المحفزة لتحقيق الأهداف & 4 \\
\hline 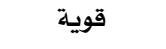 & 2.11 & الوضوح والدقة في التخطيط للدرس من حيث الصياغة والإعداد & 5 \\
\hline 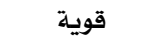 & 2.65 & الخطة التعليمية تراعي تطبيقها وفق إمكانيات المدرسة & 6 \\
\hline 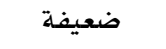 & 1.32 & تحديد مجالات الأهداف المعرفية والوجدانية والمهارية & 7 \\
\hline 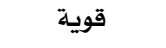 & 2.43 & تراعي خطة الدرس مستوى التلامذة عند التخطيط & 8 \\
\hline 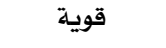 & 2.19 & مراعاة ميول واهتمامات وحاجات التلامدة عند التخطيط & 9 \\
\hline 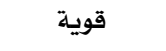 & 2.11 & عند التخطيط مراعاة التوزيع الزمني الدقيق (سنوية، فصلية ,00) & 10 \\
\hline 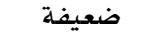 & 1.58 & تحديد أساليب التقويم وأنواعه عند التخطيط & 11 \\
\hline 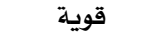 & 2.56 & عند التخطيط تحدد الوسائل التعليمية المناسبة للتدريس & 12 \\
\hline 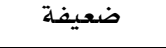 & 1.55 & تصميم الوسائل التعليمية المناسبة واللازمة للتدريس & 13 \\
\hline 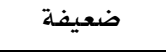 & 1.67 & التحقق من فعالية الوسائل التعليمية قبل العرض للدرس & 14 \\
\hline 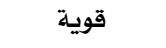 & 2.54 & استعمال الوسائل التعليمية بكفاءة ودقة عالية & 15 \\
\hline 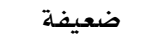 & 1.23 & عند التخطيط يراعى تحليل المحتوى التعليمي المراد تدريسه & 16 \\
\hline 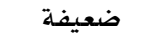 & 1.78 & وضع خطة تدريسية مرنة قابلة للتعديل وفق الموقف التدريسي & 17 \\
\hline 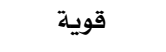 & 2.12 & تحديد الاستراتيجيات والطرائق الفعالة والملائمة لتنفيذ الأهداف & 18 \\
\hline 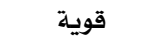 & 2.45 & تشجيع روح الابتكار والاكتشاف لدى التلامدة & 19 \\
\hline 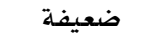 & 2.75 & التركيز على الجانب النظري في التدريس & 20 \\
\hline 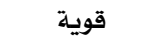 & 2.32 & تضمين الخطة أنشطة متنوعة وكافية لتغطية الدرس والموضوع & 21 \\
\hline
\end{tabular}

Al-Jizani, H. (2019). Educational competencies of mathematics teachers from their point of view in the light of variables (educational qualification, years of service, gender). Journal Port Science Research, 2(1), 185-202. 
j. port. sci. res. Volume: 2, No:1

\begin{tabular}{|c|c|c|c|}
\hline قوية & 2.65 & توجيه الهناقشات بين التلامدة أثناء الدرس & 22 \\
\hline 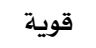 & 2.35 & اعتماد المعلم على الكتاب المدرسي فقط للتدريس & 23 \\
\hline 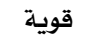 & 2.33 & استغلال وقت الدرس بشكل فعال & 24 \\
\hline قوية & 2.24 & المتابعة المستمـرة لمدى تنفيذ التلامدة للأنشطة الصفية & 25 \\
\hline 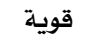 & 2.23 & مـراعاة أن يكون للتلامدة المـحور الأكبر في تنفيذ الخطة & 26 \\
\hline 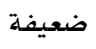 & 1.59 & التركيز على الجانب العملي في التدريس & 27 \\
\hline 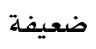 & 1.24 & اعتماد (جدول المواصفات) أو الخارطة الاختبارية عند صياغة الاختبارات & 28 \\
\hline 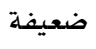 & 1.54 & مراعاة أدوات التقويهم للجوانب الشخصية للتلامذة & 29 \\
\hline 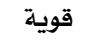 & 2.11 & تهيئة البيئة الصفية بشكل يضمن تحقيق الأهداف التدريسيـة & 30 \\
\hline قوية & 2.37 & اكتشاف نقاط القوة والضعف لدى التلامدة & 31 \\
\hline قوية & 2.32 & أكتفي بقياس التحصيل للتلامذة من خلال الاختبارات فقط & 32 \\
\hline قوية & 2.44 & تنويع الاسئلة في الاختبـارات الصفية & 33 \\
\hline 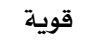 & 2.32 & أمتلك مهارة توجيه الأسئلة الصفية & 34 \\
\hline 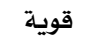 & 2.67 & أمتلك مهارة المعالجات لإجابات التلامدة & 35 \\
\hline 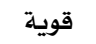 & 2.86 & أمتلك مهارة صياغة الأسئلة الصفية & 36 \\
\hline ضعيفة & 1.66 & تنويع المثيرات داخل غرفة الصف & 37 \\
\hline ضعيفة & 1.73 & الاطلاع على اجابات التلامذة وتزويدهم بتغذيـة راجعة فوريـة مكتوبة أو لفظية & 38 \\
\hline قوية & 2.34 & جذب انتبـاه التلامدة والمـحافظة على استمـراريته & 39 \\
\hline قوية & 2.43 & استعمال ألفاظ سليمة في التدريس نطقا وكتابة & 40 \\
\hline ضعيفة & 1.32 & استعمال الأنشطة الاثرائية والعلاجية عند الضرورة خلال التدريس & 41 \\
\hline 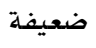 & 1.56 & مـراعاة الفروق الفردية في توزيـع الأنشطة والمهام الصفية & 42 \\
\hline 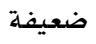 & 1.45 & تقويم التلامدة وفق أسس ومعايير مححددة مسبقا ودقيقة & 43 \\
\hline 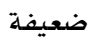 & 1.78 & مراعاة أسـاليب التقويم للفروق الفردية بين التلامدة & 44 \\
\hline 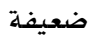 & 1.65 & مساعدة التلامذة على التقويم الذاتي & 45 \\
\hline 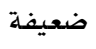 & 1.88 & أثارة دافعية التلامدة للتعلهم بوسائل مختلفة & 46 \\
\hline 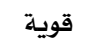 & 2.73 & صياغة الفقرات والأسئلة التقويمية بطريقة واضحة ومحددة & 47 \\
\hline ضعيفة & 1.54 & مـراعاة الاستمـرارية في عملية التقويه & 48 \\
\hline ضعيفة & 1.65 & اشتقاق فقرات الاختبـار من الأهداف السلوكية & 49 \\
\hline ضعيفة & 1.75 & تحليل نتائج الاختبار للاستفادة منها في تعديل تدريسها & 50 \\
\hline
\end{tabular}

نستنتج من الجدول أعلاه أن نسبة الكفايات التعليمية لدى معلمي ومعلمات الرياضيات للصف السـادس

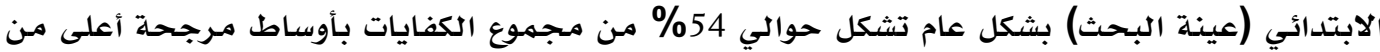

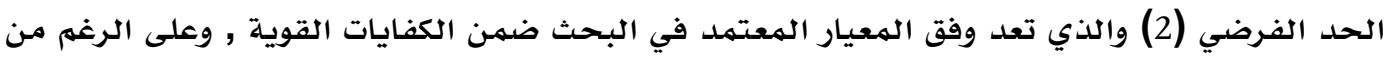

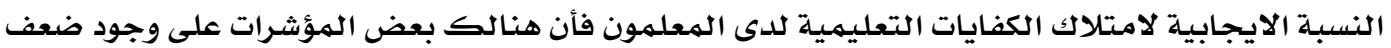
في بعض الكفايات التعليمية وكما مشار أليها في الجدول أعلاه تحتاخ الى برامج تدريبية وتطويرية مستمـرة لتطويرها واستعمالها وتوظيفها بشكل أفضل في تدريس الرياضيات. 
السؤال الثاني ما مدى امتلاكك معلمي ومعلمات الرياضيات للكفايات التعليمية من وجهة نظرهم في ضوء اختلاف المؤهل العلمي. وتتهم الإجابة على السؤال الحالي من خلال تقديرات معلمي ومعلمات التات الرياضيات الريات

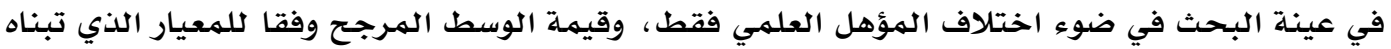
الباحث للفصل بين ناحيتي القوة والضعف للكفايات التعليمية المتمثلة بفقرات الاستبانة وكما موضح فئح

جدول رقم (3) عينة البحث في ضوء اختلاف الهؤهل العلمي وقيمة الوسط المرجح

\begin{tabular}{|c|c|c|c|c|c|}
\hline الكفاية & $\begin{array}{c}\text { الوسط المرجح لمعلمي ومعلمات } \\
\text { الرؤهل العلمي بكالوريوس) }\end{array}$ & الكفاية & الوسط المرجح لمعلمي & المرجح العام & تسلسل \\
\hline قوية & 2.53 & ضعيفة & 1.77 & 2.15 & 1 \\
\hline ضعيفة & 1.56 & ضعيفة & 0.88 & 1.22 & 2 \\
\hline ضعيفة & 1.82 & ضعيفة & 1.30 & 1.56 & 3 \\
\hline قوية & 2.51 & قوية & 2.11 & 2.31 & 4 \\
\hline قوية & 2.18 & قوية & 2.04 & 2.11 & 5 \\
\hline قوية & 2.90 & قوية & 2.40 & 2.65 & 6 \\
\hline ضعيفة & 1.75 & ضعيفة & 0.89 & 1.32 & 7 \\
\hline قوية & 2.65 & قوية & 2.21 & 2.43 & 8 \\
\hline قوية & 2.26 & قوية & 2.12 & 2.19 & 9 \\
\hline قوية & 2.15 & قوية & 2.07 & 2.11 & 10 \\
\hline ضعيفة & 1.86 & ضعيفة & 1.30 & 1.58 & 11 \\
\hline قوية & 2.79 & قوية & 2.33 & 2.56 & 12 \\
\hline ضعيفة & 1.89 & ضعيفة & 1.21 & 1.55 & 13 \\
\hline ضعيفة & 1.93 & ضعيفة & 1.41 & 1.67 & 14 \\
\hline قوية & 2.87 & قوية & 2.21 & 2.54 & 15 \\
\hline ضعيفة & 1.40 & ضعيفة & 1.06 & 1.23 & 16 \\
\hline ضعيفة & 1.95 & ضعيفة & 1.61 & 1.78 & 17 \\
\hline قوية & 2.17 & قوية & 2.07 & 2.12 & 18 \\
\hline قوية & 2.58 & قوية & 2.32 & 2.45 & 19 \\
\hline قوية & 2.96 & قوية & 2.54 & 2.75 & 20 \\
\hline قوية & 2.53 & قوية & 2.11 & 2.32 & 21 \\
\hline قوية & 2.96 & قوية & 2.34 & 2.65 & 22 \\
\hline قوية & 2.48 & قوية & 2.22 & 2.35 & 23 \\
\hline قوية & 2.51 & قوية & 2.15 & 2.33 & 24 \\
\hline قوية & 2.35 & قوية & 2.13 & 2.24 & 25 \\
\hline قوية & 2.59 & ضعيفة & 1.87 & 2.23 & 26 \\
\hline قوية & 2.29 & ضعيفة & 0.89 & 1.59 & 27 \\
\hline قوية & 2.01 & ضعيفة & 0.47 & 1.24 & 28 \\
\hline قوية & 2.63 & ضعيفة & 0.45 & 1.54 & 29 \\
\hline قوية & 2.20 & قوية & 2.02 & 2.11 & 30 \\
\hline قوية & 2.63 & قوية & 2.11 & 2.37 & 31 \\
\hline قوية & 2.49 & قوية & 2.15 & 2.32 & 32 \\
\hline قوية & 2.80 & قوية & 2.08 & 2.44 & 33 \\
\hline
\end{tabular}

Al-Jizani, H. (2019). Educational competencies of mathematics teachers from their point of view in the light of variables (educational qualification, years of service, gender). Journal Port Science Research, 2(1), 185-202. 
j. port. sci. res.

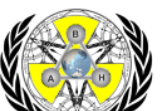

Journal port Science Research Available online www.jport.co Volume: 2, No:1

\begin{tabular}{|c|c|c|c|c|c|}
\hline قوية & 2.52 & قوية & 2.12 & 2.32 & 34 \\
\hline قوية & 2.79 & قوية & 2.55 & 2.67 & 35 \\
\hline قوية & 2.92 & قوية & 2.80 & 2.86 & 36 \\
\hline قوية & 2.67 & ضعيفة & 0.65 & 1.66 & 37 \\
\hline ضعيفة & 1.91 & ضعيفة & 1.55 & 1.73 & 38 \\
\hline قوية & 2.48 & قوية & 2.20 & 2.34 & 39 \\
\hline قوية & 2.73 & قوية & 2.13 & 2.43 & 40 \\
\hline قوية & 2.19 & ضعيفة & 0.45 & 1.32 & 41 \\
\hline قوية & 2.56 & ضعيفة & 0.56 & 1.56 & 42 \\
\hline ضعيفة & 1.58 & ضعيفة & 1.32 & 1.45 & 43 \\
\hline ضعيفة & 1.91 & ضعيفة & 1.65 & 1.78 & 44 \\
\hline ضعيفة & 1.63 & ضعيفة & 1.67 & 1.65 & 45 \\
\hline ضعيفة & 1.92 & ضعيفة & 1.84 & 1.88 & 46 \\
\hline قوية & 2.79 & قوية & 2.67 & 2.73 & 47 \\
\hline ضعيفة & 1.68 & ضعيفة & 1.40 & 1.54 & 48 \\
\hline ضعيفة & 1.60 & ضعيفة & 1.70 & 1.65 & 49 \\
\hline ضعيفة & 1.86 & ضعيفة & 1.64 & 1.75 & 50 \\
\hline
\end{tabular}

نستنتج من الجدول أعلاه هنالك تباين بين نسبة الكفايات التعليمية لدى معلمي ومعلمات الرياضيات

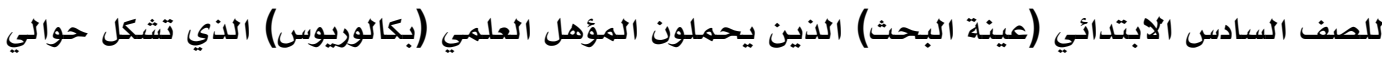

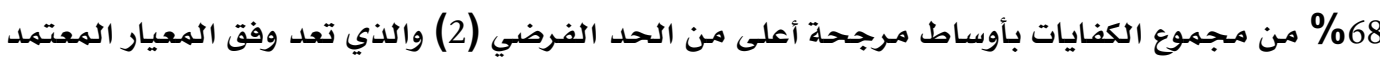

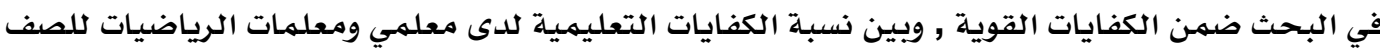

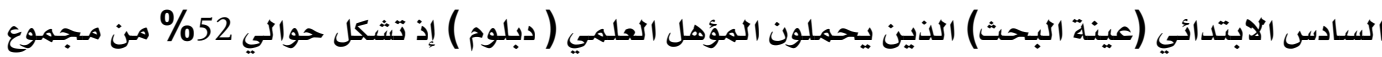

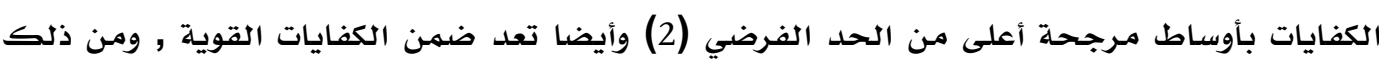

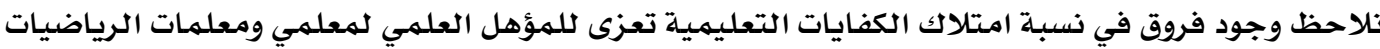

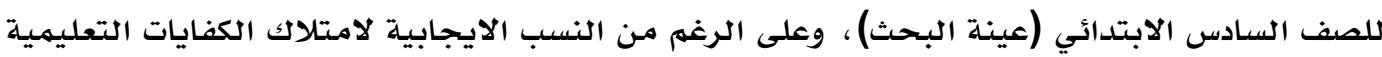

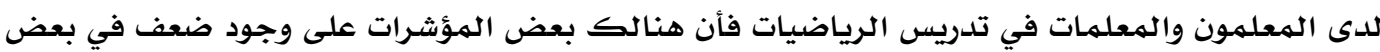

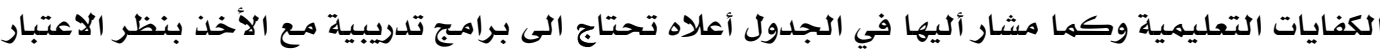
المؤهل العلمي لمعلمي ومعلمات الرياضيات وكفاياتهم التعليمية.

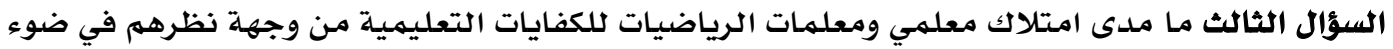

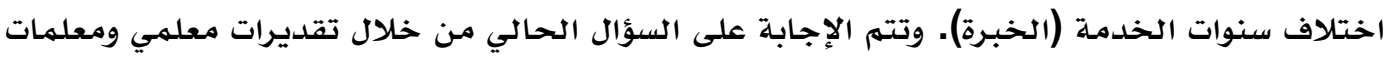

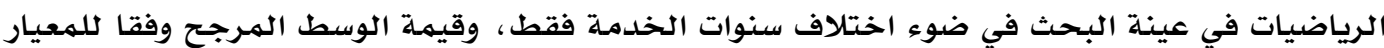
الذي تبناه الباحث للفصل بين ناحيتي القوة والضعف للكفايات التعليمية المتمثلة بفقرات الاستبانة

$$
\text { وكما موضح في جدول رقم (4). }
$$

جلدول رقه (4) عينة البحث في ضوء اختلاف سنوات الخدمة وقيمة الوسط المرجح

\begin{tabular}{|c|c|c|c|c|c|}
\hline الكفاية & $\begin{array}{c}\text { الوسط المرجح لمعلمي ومعلمات الرياضيات } \\
\text { الخدمة (10سنوات فما فوق) }\end{array}$ & الكفاية & 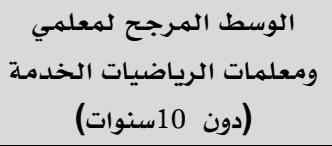 & الموسط العرج & الكفاية \\
\hline قوية & 2.29 & قوية & 2.01 & 2.15 & 1 \\
\hline ضعيفة & 1.79 & ضعيفة & 0.65 & 1.22 & 2 \\
\hline
\end{tabular}

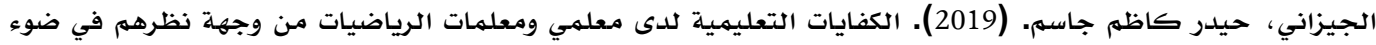
متغيرات (المؤهل العلهي، سنوات الخدمة، الجنس). Journal Port Science Research، 2 (1)، 


\begin{tabular}{|c|c|c|c|c|c|}
\hline قوية & 2.34 & ضعيفة & 0.78 & 1.56 & 3 \\
\hline قوية & 2.51 & قوية & 2.11 & 2.31 & 4 \\
\hline قويـة & 2.20 & قوية & 2.02 & 2.11 & 5 \\
\hline قوية & 2.95 & قوية & 2.35 & 2.65 & 6 \\
\hline ضعيفة & 1.75 & ضعيفة & 0.89 & 1.32 & 7 \\
\hline قوية & 2.74 & قوية & 2.12 & 2.43 & 8 \\
\hline قوية & 2.29 & قوية & 2.09 & 2.19 & 9 \\
\hline قوية & 2.20 & قوية & 2.02 & 2.11 & 10 \\
\hline قوية & 2.60 & ضعيفة & 0.56 & 1.58 & 11 \\
\hline قوية & 2.69 & قوية & 2.43 & 2.56 & 12 \\
\hline ضعيفة & 1.87 & ضعيفة & 1.23 & 1.55 & 13 \\
\hline ضعيفة & 1.90 & ضعيفة & 1.44 & 1.67 & 14 \\
\hline قويـة & 2.85 & قوية & 2.23 & 2.54 & 15 \\
\hline ضعيفة & 1.34 & ضعيفة & 1.12 & 1.23 & 16 \\
\hline قوية & 2.52 & ضعيفة & 1.04 & 1.78 & 17 \\
\hline قوية & 2.56 & ضعيفة & 1.68 & 2.12 & 18 \\
\hline قوية & 2.75 & قوية & 2.15 & 2.45 & 19 \\
\hline قوية & 2.90 & قوية & 2.60 & 2.75 & 20 \\
\hline قوية & 2.50 & قوية & 2.14 & 2.32 & 21 \\
\hline قوية & 2.93 & قوية & 2.37 & 2.65 & 22 \\
\hline قوية & 2.59 & قوية & 2.11 & 2.35 & 23 \\
\hline قوية & 2.35 & قوية & 2.31 & 2.33 & 24 \\
\hline قوية & 2.32 & قوية & 2.16 & 2.24 & 25 \\
\hline قوية & 2.03 & قوية & 2.43 & 2.23 & 26 \\
\hline ضعيفة & 1.73 & ضعيفة & 1.45 & 1.59 & 27 \\
\hline قويـة & 1.26 & ضعيفة & 1.22 & 1.24 & 28 \\
\hline قوية & 2.41 & ضعيفة & 0.67 & 1.54 & 29 \\
\hline قوية & 2.25 & ضعيفة & 1.97 & 2.11 & 30 \\
\hline قوية & 2.83 & ضعيفة & 1.91 & 2.37 & 31 \\
\hline قوية & 2.72 & ضعيفة & 1.92 & 2.32 & 32 \\
\hline قويـة & 2.93 & ضعيفة & 1.95 & 2.44 & 33 \\
\hline قوية & 2.76 & ضعيفة & 1.88 & 2.32 & 34 \\
\hline قوية & 2.80 & قوية & 2.54 & 2.67 & 35 \\
\hline قويـة & 2.93 & قوية & 2.79 & 2.86 & 36 \\
\hline قوية & 2.72 & ضعيفة & 0.60 & 1.66 & 37 \\
\hline قوية & 2.13 & ضعيفة & 1.33 & 1.73 & 38 \\
\hline قوية & 2.25 & قوية & 2.43 & 2.34 & 39 \\
\hline قوية & 2.50 & قوية & 2.36 & 2.43 & 40 \\
\hline ضعيفة & 1.62 & ضعيفة & 1.02 & 1.32 & 41 \\
\hline ضعيفة & 1.78 & ضعيفة & 1.34 & 1.56 & 42 \\
\hline ضعيفة & 1.67 & ضعيفة & 1.23 & 1.45 & 43 \\
\hline ضعيفة & 1.88 & ضعيفة & 1.68 & 1.78 & 44 \\
\hline
\end{tabular}

Al-Jizani, H. (2019). Educational competencies of mathematics teachers from their point of view in the light of variables (educational qualification, years of service, gender). Journal Port Science Research, 2(1), 185-202. 
j. port. sci. res.

\begin{tabular}{|c|c|c|c|c|c|}
\hline ضعيفة & 1.85 & ضعيفة & 1.45 & 1.65 & 45 \\
\hline ضعيفة & 1.97 & ضعيفة & 1.79 & 1.88 & 46 \\
\hline قوية & 2.83 & قوية & 2.63 & 2.73 & 47 \\
\hline ضعيفة & 1.76 & ضعيفة & 1.32 & 1.54 & 48 \\
\hline ضعيفة & 1.72 & ضعيفة & 1.58 & 1.65 & 49 \\
\hline قوية & 2.15 & ضعيفة & 1.35 & 1.75 & 50 \\
\hline
\end{tabular}

نستنتج من الجدول أعلاه هنالك تباين بين نسبة الكفايات التعليمية لدى معلمي ومعلمات الرياضيات للصف السادس الابتدائي (عينة البحث) الذين خدمتهم وسنوات الخبرة لديهم في الوظيفة ( أقل من

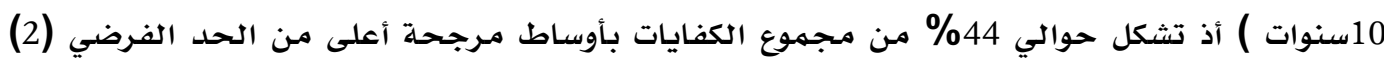
والذي تعد وفق المعيار المعتمد في البحث ضمن الكفايات القوية , وبين نسبة الكفايات التعليمية لدى لهى

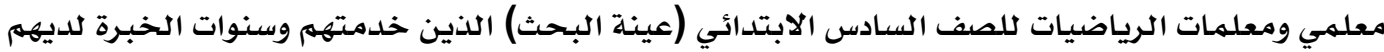

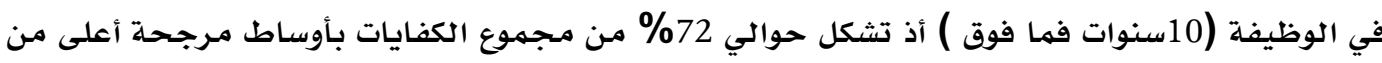

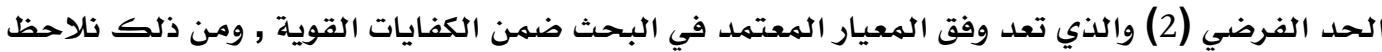
وجود فروق في نسبة امتلاكك الكفايات التعليمية تعزى لسنوات الخدمـة لمعلمي ومعلمات الرياضيات للصف السادس الابتدائي ( عينة البحث ) , وعلى الرغم من النسب الايجابية لامتلاكك الكفايات التعليمية لدى لدى

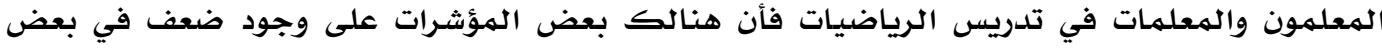
الكفايات التعليميلة وكما مشار أليها في الجدول أعلاه تحتاج الى برامـج تدريبية مـع الأخذ بنظر الاعتبار سنوات الخدمة في تدريس الرياضيات لمعلمي ومعلمات الرياضيات . السؤال الرابع ما مدى امتتلاك معلهي ومعلمات الرياضيات للكفايات التعليهية من وجهة نظرهم في ضوء اختاف الجنس. وتتم الإجابة على السؤال الحالي من خلال تقديرات معلمي ومعلمات الريات الرياضيات في عينة البحث في ضوء اختلاف الجنس، وقيمة الوسط المرجح وفقا للمعيار الذي تبناه الباحث للفصل بين ناحيتي القوة والضعف للكفايات التعليمية المتمثلة بفقرات الاستبانة وكما موضـح في جلدول رقم (5). جلدول (5) تقلديرات معلمسي ومعلمات الرياضيات في عينة البحث في ضوء اختلاف الجنس

\begin{tabular}{|c|c|c|c|c|c|}
\hline تقويم & $\begin{array}{c}\text { الوسط المرجح لمعلماضيات (إناث) } \\
\text { الريات }\end{array}$ & الكفاية & الرسط المرجح لمعلمي & الوسط المـرجـح & تسلسل \\
\hline قوية & 2.19 & قوية & 2.11 & 2.15 & 1 \\
\hline ضعيفة & 1.68 & ضعيفة & 0.76 & 1.22 & 2 \\
\hline ضعيفة & 1.79 & ضعيفة & 1.33 & 1.56 & 3 \\
\hline قويـة & 2.50 & قوية & 2.12 & 2.31 & 4 \\
\hline قوية & 2.20 & قوية & 2.02 & 2.11 & 5 \\
\hline قوية & 2.64 & قوية & 2.66 & 2.65 & 6 \\
\hline ضعيفة & 1.51 & ضعيفة & 1.13 & 1.32 & 7 \\
\hline قوية & 2.53 & قوية & 2.33 & 2.43 & 8 \\
\hline قوية & 2.37 & قوية & 2.01 & 2.19 & 9 \\
\hline قوية & 2.7 & قوية & 2.15 & 2.11 & 10 \\
\hline قوية & 2.03 & ضعيفة & 1.13 & 1.58 & 11 \\
\hline قوية & 2.52 & قوية & 2.60 & 2.56 & 12 \\
\hline ضعيفة & 1.43 & ضعيفة & 1.67 & 1.55 & 13 \\
\hline
\end{tabular}

الجيزاني، حيدر كاظم جاسهم. (2019). الكفايات التعليمية لدى معلمي ومعلمات الرياضيات من وجهة نظرهم في ضوء التهات

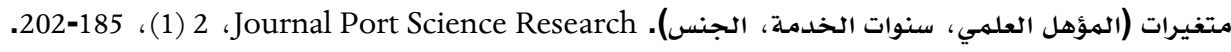


Journal port Science Research

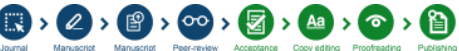

\begin{tabular}{|c|c|c|c|c|c|}
\hline ضعيفة & 1.79 & ضعيفة & 1.55 & 1.67 & 14 \\
\hline قويـة & 2.43 & قويـة & 2.65 & 2.54 & 15 \\
\hline ضعيفة & 1.42 & ضعيفة & 1.04 & 1.23 & 16 \\
\hline قوية & 2.23 & ضعيفة & 1.33 & 1.78 & 17 \\
\hline قوية & 2.19 & قوية & 2.05 & 2.12 & 18 \\
\hline
\end{tabular}

\begin{tabular}{|c|c|c|c|c|c|}
\hline قوية قوية & 2.33 & 2.57 & 2.45 & 19 \\
\hline قوية ضعيفة & 2.70 & 2.80 & 2.75 & 20 \\
\hline ضوية قوية & 2.31 & 2.33 & 2.32 & 21 \\
\hline قوية & 2.76 & 2.54 & 2.65 & 22 \\
\hline
\end{tabular}

\begin{tabular}{|l|l|l|l|l|l|}
\hline قوية & 2.48 & 2.22 & 2.35 & 23 \\
\hline قوية قوية قوية & 2.53 & 2.13 & 2.33 & 24 \\
\hline قوية قوية قوية & 2.04 & 2.44 & 2.24 & 2.23 \\
\hline قوية & 2.32 & 1.85 & 1.60 & 1.59 & 26 \\
\hline
\end{tabular}

\begin{tabular}{|c|c|c|c|c|c|}
\hline & & & & & \\
\hline قوية & 1.85 & ضعيفة & 1.60 & 1.59 & 27 \\
\hline ضعيفة & 1.15 & ضعيفة & 1.33 & 1.24 & 28 \\
\hline قوية & 1.62 & ضعيفة & 1.46 & 1.54 & 29 \\
\hline قوية & 2.14 & قوية & 2.08 & 2.11 & 30 \\
\hline قوية & 2.59 & قوية & 2.15 & 2.37 & 31 \\
\hline قويـة & 1.98 & ضعيفة & 2.66 & 2.32 & 32 \\
\hline
\end{tabular}

\begin{tabular}{|c|c|c|c|c|c|}
\hline قويـة & 2.59 & قوية & 2.15 & 2.37 & 31 \\
\hline قويـة & 1.98 & ضعيفة & 2.66 & 2.32 & 32 \\
\hline قويـة & 2.69 & قويـة & 2.19 & 2.44 & 33 \\
\hline قوية & 2.50 & قويـة & 2.14 & 2.32 & 34 \\
\hline قويـة & 2.57 & قوية & 2.77 & 2.67 & 35 \\
\hline قويـة & 2.83 & قوية & 2.89 & 2.86 & 36 \\
\hline
\end{tabular}

\begin{tabular}{|c|c|c|c|c|c|}
\hline & & & & & \\
\hline قوية & 2.83 & قوية & 2.89 & 2.86 & 36 \\
\hline قوية & 2.20 & ضعيفة & 1.12 & 1.66 & 37 \\
\hline قوية & 2.03 & ضعيفة & 1.43 & 1.73 & 38 \\
\hline قوية & 2.24 & قوية & 2.44 & 2.34 & 39 \\
\hline قويـة & 2.21 & قوية & 2.65 & 2.43 & 40 \\
\hline
\end{tabular}

\begin{tabular}{|c|c|c|c|c|c|}
\hline قوية & 2.21 & قوية & 2.65 & 2.43 & 40 \\
\hline ضعيفة & 1.55 & ضعيفة & 1.09 & 1.32 & 41 \\
\hline ضعيفة & 1.79 & ضعيفة & 1.33 & 1.56 & 42 \\
\hline ضعيفة & 1.37 & ضعيفة & 1.53 & 1.45 & 43 \\
\hline ضعيفة & 1.86 & ضعيفة & 1.70 & 1.78 & 44 \\
\hline ضعيفة & 1.76 & ضعيفة & 1.54 & 1.65 & 45 \\
\hline ضعيفة & 1.85 & ضعيفة & 1.91 & 1.88 & 46 \\
\hline قوية & 2.86 & قوية & 2.60 & 2.73 & 47 \\
\hline ضعيفة & 1.42 & ضعيفة & 1.66 & 1.54 & 48 \\
\hline ضعيفة & 1.67 & ضعيفة & 1.53 & 1.65 & 49 \\
\hline ضعيفة & 1.95 & ضعيفة & 1.55 & 1.75 & 50 \\
\hline
\end{tabular}

نستنتج من الجدول أعلاه هنالك تباين بين نسبة الكفايات التعليمية لدى (معلمي الرياضيات) للصف

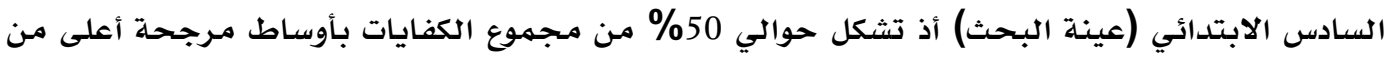

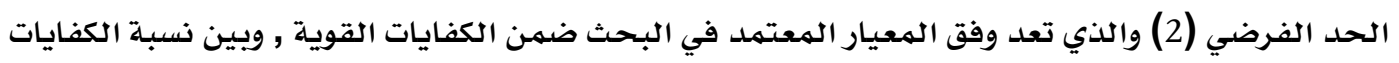

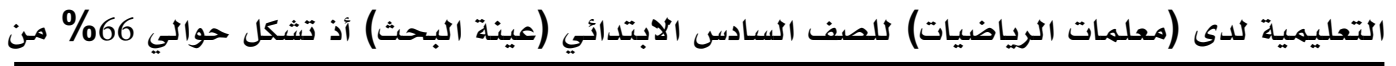

Al-Jizani, H. (2019). Educational competencies of mathematics teachers from their point of view in the light of variables (educational qualification, years of service, gender). Journal Port Science Research, 2(1), 185-202. 
مجموع الكفايات بأوساط مرجحة أعلى من الحد الفرضي (2) والذي تعد وفق المعيار المعتمد في البحث

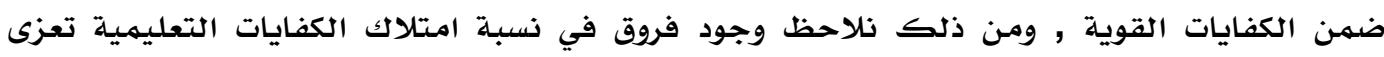

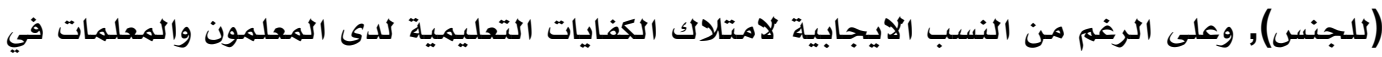

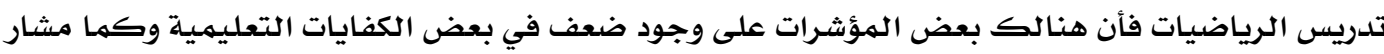

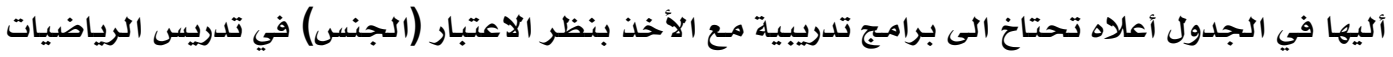

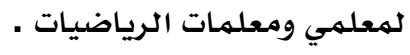

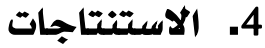

في ضوء التقديرات التقويمية لمعلمي ومعلمات الرياضيات للصف السادس الابتدائي (عينة البحث) حول

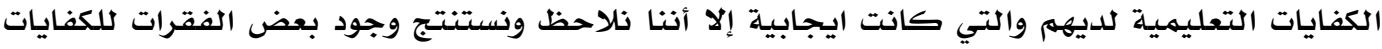

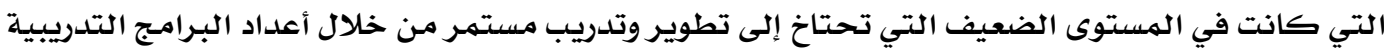

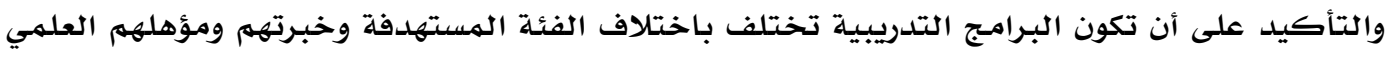

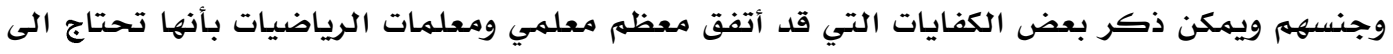

$$
\begin{aligned}
& \text { تطوير وتدريب وكهما يأتي وني } \\
& \text { تحليل المحتوى الرياضيات. } \\
& \text { تصنيف الأهداف السلوكية للمستويات العليا في التفكير. } \\
& \text { أبعاد مجالات الأهداف المعرفية والوجدانية والمهارية. } \\
& \text { تحديد أسـاليب التقويهم وأنواعه عند التخطيط. } \\
& \text { تصميهم الوسائل التعليميـة المناسبـة اللازمهة للتدريس. } \\
& \text { التحقق من فعالية الوسـائل التعليهية قبل العرض للسرس. } \\
& \text { كيفية وضع خطة تدريسية مـرنة قابلة للتعديل وفق الموقف التدريسي. } \\
& \text { التركيز على الجـانب العملي في التدريس. } \\
& \text { اعتمـاد (جدول المواصفات) أو الخارطة الاختبارية عند صياغة الاختبارات. } \\
& \text { مـراعاة أدوات التقويهم للجوانب الشخصيـة للتلامدة. } \\
& \text { تنويع المثيرات داخل غرفة الصف. } \\
& \text { الاطلاع على إجابات التلامدة وتزويدهم بتغذية راجعة فورية مكتوبة أو لفظية. } \\
& \text { استعمال الأنشطة الاثرائية والعلاجية عند الضسرورة خلال التدريس. } \\
& \text { مراعاة الفروق الفردية في توزيع الأنشطة والههام الصفية. } \\
& \text { تقويهم التلامدة وفق أسس ومعايير مححدة مسبقا ودقيقة. } \\
& \text { مـراعاة أساليب التقويهم للفروق الفرديـة بين التلامدة. } \\
& \text { مسـاعدة التلامدة على التقويم الذاتي. } \\
& \text { أثارة دافعية التلامذة للتعلهم بوسائل مختلفية. } \\
& \text { مراعاة الاستمراريـة في عملية التقويه. } \\
& \text { اشتقاق فقرات الاختبار من الأهداف السلوكية. } \\
& \text { تحليل نتائج الاختبار للاستفادة منها في تعديل تدريسها. }
\end{aligned}
$$


كان الغرض من البحث هو الكثف عن الكفايات التعليمية لدى معلمي ومعلمات الرياضيات من وجهة نظرهم في ضوء متغيرات (المؤهل العلمي، سنوات الخدمة، الجنس) وذلك بالبحث عن نقاط القوة والضعف ومحاولة معالجتها باقتراح الحلول المناسبة وفيما يأتي أبرز وأهم التوصيات التي قد تسـاهم في تطوير الكفايات التعليمية لدى معلمي ومعلمات الرياضيات بالاعتماد على ما تم التوصل إليه من خلال استنتاجات البحث وكما يأتي:

ضرورة استفادة القائمين على العملية التربوية والمختصين في أقسام الإعداد والتدريب وأقسام الإشراف التريوي من قائمسة الكفايات التعليمية التي قام الباحث بأعدادها وتطويرها في تصهيم

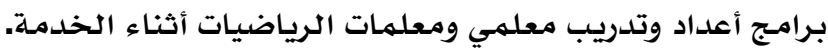

تكثيف الدورات التدريبية من قبل التربويين والاختصاصيين كنماذخ تطبيقية لتطوير كفايات معلهي ومعلمات الرياضيات.

حث الاختصاصيين التريويين من المعلمون والقائمون على العملية التريوية والتعليمية بالاهتمام بالتعلهم الذاتي لما له الأثر الايجابي والكبير في عملية ديمومة التطور المهني واستمراريته. تفعيل نظام التدريب أثناء الخدمة لمعلهي الرياضيات لتطوير كفاياتهم التدريسية. اعتماد استبانة الكفايات التعليمية لأغراض التقويه وتدريب معلمو الرياضيات بصورة خاصلة والمواد التدريسية الأخرى بصورة عامـة.

المقترحات

استكمالا للبحث يقترح الباحث ما يأتي:

1) أجراء دراسات مهاثلة للكفايات التدريسية لدى مدرسي الرياضيات في المرحلة المتوسطة

$$
\text { والإعدادية. }
$$

2) أجراء دراسـات تكشف عن أهم الكفايات التعليمية والأكثر ضرورة والتي يحتاجها المعلمون خلال

$$
\text { تدريسهم لكتب الرياضيات الجديدة واقتراحاتهم لسبل تطويرها. }
$$

3) توسيع قاعدة البحث من خلال توسيع مجتمـع البحث وإشراك أطراف أخرى في تقويم معلمي ومعلمات الرياضيات في مدى امتلاكهم للكفايات التعليمية مثل (المشرفون، إدارات المدارس،

$$
\text { أولياء الأمور، التلامدة). }
$$

\section{References}

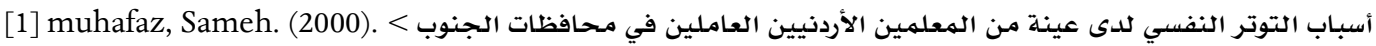
> Journal of Educational and Psychological Sciences, Volume 9, No. 4. https: / / arabci.org/Articles?id=38775

Al-Jizani, H. (2019). Educational competencies of mathematics teachers from their point of view in the light of variables (educational qualification, years of service, gender). Journal Port Science Research, 2(1), 185-202. 
[2] Bransford, J. D., Brown, A. L., \& Cocking, R. R. (2000). How People Learn: Brain, Mind, Experience, and School. Committee on learning research and educational practice (Vol. Expanded E, pp. x, 374 p.). https:// doi.org/10.1016/0885-2014(91)90049-J

[3] Ali, Nabil. (2001). الثقافة العربية وعصر المعلومات> Kuwait: National Council for Culture, Arts and Letters. https: / / www.goodreads.com/book/show/ 7718560

[4] Marei, Tawfiq Ahmed Yousef. (1982). الكفايات التعليمية الأدائية الأساسية عند معلم المدرسة الابتدائية في . (Doctoral dissertation) Egypt, Ain Shams University. http:/ / repository.yu.edu.jo/handle/123456789/567359

[5] Bruwelheide, J. (1982). Teacher Competencies for Microcomputer Use in the Classroom: A Literature Review. Educational Technology Publications, Inc, Vol. 22, pp. 29-31. https:/ / www.jstor.org/stable/ 44423738

[6] Ananiadou, K., \& Claro, M. (2009). 21st century skills and competences for new millennium learners in OECD countries. OECD Education Working Papers, (41), 33. https:// doi.org/10.1787/218525261154

[7] Khawaldeh, Mohammed Mahmoud. (1986). تصورات المشتغلين في إعداد المعلمين للكفايات التعليمية الكلازمة لمعلمي المرحلة الإلزامية في الأردن http: / / pubcouncil.kuniv.edu.kw/joe/homear.aspx?id=8\&Root=yes\&authid=980

[8] Saadada, Jawdat Ahmed. \& Ibrahim, Abdullah Mohammed (2001). تنظيمات المناهج وتخطيطها > Amman: Dar Al Shorouq.https:/ / libserver.bethlehem.edu/webopac/records/1/66290.aspx

[9] Al-Mufleh, Daad Jalal. (1990). اعداد معلمي التربية الفنية في ضوء الكفايات و أثره في تحصيل طلبة الصف العاشر>. (Master Thesis) Jordan: Yarmouk University, Faculty of Education and Arts http:/ / repository.yu.edu.jo/jspui/handle/123456789/553281

[10] Jame, Hassan \& Al-Shaheen, Hessa \& Hadi, Fawzia. (1984). الكفاءات التدريسية الكلازمة لمعلم المرحلة الابتدائية في مولة الكويت ال Kuwait: Educational Journal, Volume: 1 Issue: 2. http:/ / pubcouncil.kuniv.edu.kw/joe/ homear.aspx?id=8\&Root=yes\&authid=711

[11] Bembenutty, H., White, M. C., \& Vélez, M. R. (2015). Developing Self-regulation of Learning and Teaching Skills Among Teacher Candidates. Dordrecht: Springer Netherlands. https: / / doi.org/10.1007/978-94-017-9950-8

[12] Koster, B., Brekelmans, M., Korthagen, F., \& Wubbels, T. (2005). Quality requirements for teacher educators. Teaching and Teacher Education, 21(2), 157-176. https: / / doi.org/10.1016/j.tate.2004.12.004

[13] Najjar, Hassan Abdullah Mohammed \& Ghazawi, Mohammed Theban \& Ahmed Suleiman Odeh. مدى توافر الكفايات التقنية التعليمية لدى معلمي مرحلة التعليم الاساسي في الأردن و ممارستهم لها من وجهة > . (1997) نظر المعلمين انفسه > >. >. (Master Thesis) Jordan: Yarmouk University, Faculty of Education and Arts http:/ / repository.yu.edu.jo/jspui/handle/123456789/560946

[14] Trigwell, K., Prosser, M., \& Waterhouse, F. (1999). Relations between teachers' approaches to teaching and students' approaches to learning. Higher Education, 37(1), 57-70. https: / / doi.org/10.1023/A:1003548313194

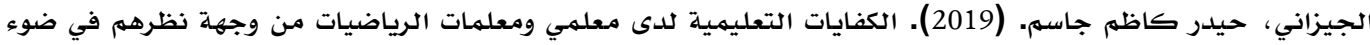
متغيرات (المؤهل العلمي، سنوات الخدمة، الجنس). Journal Port Science Research، 2 (1)، 185-202. 
[15] Jaenini, Naim Habib. (2000). الكفايات الأساسية للمعلمين في مرحلة التعليم الثانوي في الأردن من وجهة نظرهم > Jordan: Dirasat Aarabia. https:/ / alba7thon.com/?q=node/59739

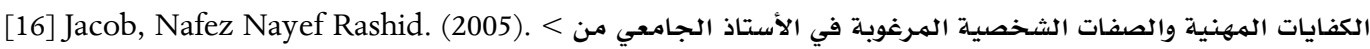
وجهة نظر طلاب كلية المعلمين في المملكة السعودية . . Arab Journal of Education, Arab League Educational, Cultural and Scientific Organization, Tunis, vol. 25, no. 1, pp. 102-141.

[17] National Council of Teachers of Mathematics. (2017). Compendium for research in mathematics education. National Council of Teachers of Mathematics (p. 1008).

[18] algharib, ramziat. (1996). التقويم والقياس النفسي التربوي> > Egyptian Anglo Library. https:/ / www.neelwafurat.com/itempage.aspx?id=egb24516-5129022\&search=books

[19] Odeh, Ahmad. (2005). القياس والتقويه: في العملية التدريسية> Jordan: Dar Al Amal for Publishing \& Distribution. https://libserver.bethlehem.edu/webopac/records/1/87296.aspx

\section{ملحق (1)}

استبانة الكفايات التعليمية لمعلهي ومعلمات الرياضيات في المرحلة الابتدائية

\begin{tabular}{|c|c|c|c|c|}
\hline نادرا & 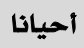 & 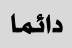 & الكفاية التعليمية & ت \\
\hline & & & اشتقاق الأهداف الخاصة والسلوكية من المحتوى التعليمي & 1 \\
\hline & & & لديك القدرة على تحليل المحتوى الرياضيات & 2 \\
\hline & & & تضمين الأهداف السلوكية للمستويات العليا في التفكير & 3 \\
\hline & & & استعمال الوسائل التعليمية والأنشطة المحفزة لتحقيق الأهداف & 4 \\
\hline & & & الوضوح والدقة في التخطيط للدرس من حيث الصياغة والإعداد & 5 \\
\hline & & & الخطة التعليمية تراعي تطبيقها وفق إمكانيات المدرسة & 6 \\
\hline & & & تحديد مجالات الأهداف المعرفية والوجدانية والمهارية & 7 \\
\hline & & & تراعي خطة الدرس مستوى التلامذة عند التخطيط & 8 \\
\hline & & & مراعاة ميول واهتمامات وحاجات التلامدة عند التخطيط & 9 \\
\hline & & & عند التخطيط مراعاة التوزيع الزمني الدقيق (سنوية، فصلية) & 10 \\
\hline & & & تحديد أساليب التقويم وأنواعه عند التخطيط & 11 \\
\hline & & & عند التخطيط تحدد الوسائل التعليمية المناسبة للتدريس & 12 \\
\hline & & & تصميم الوسائل التعليمية المناسبة واللازمة للتدريس & 13 \\
\hline & & & التحقق من فعالية الوسائل التعليمية قبل العرض للدرس & 14 \\
\hline & & & استعمال الوسائل التعليمية بكفاءة ودقة عالية & 15 \\
\hline & & & عند التخطيط يراعى تحليل المحتوى التعليمي المراد تدريسه & 16 \\
\hline & & & وضع خطة تدريسية مرنة قابلة للتعديل وفق الموقف التدريسي & 17 \\
\hline & & & تحديد الاستراتيجيات والطرائق الفعالة والملائمة لتنفيذ الأهداف & 18 \\
\hline & & & تشجيع روح الابتكار والاكتشاف لدى التلامدة & 19 \\
\hline & & & التركيز على الجانب النظري في التدريس & 20 \\
\hline & & & تضمين الخطة أنشطة متنوعة وكافية لتغطية الدرس والموضوع & 21 \\
\hline & & & توجيه المناقشات بين التلامذة أثناء الدرس & 22 \\
\hline & & & اعتماد المعلم على الكتاب المدرسي فقط للتدريس & 23 \\
\hline
\end{tabular}

Al-Jizani, H. (2019). Educational competencies of mathematics teachers from their point of view in the light of variables (educational qualification, years of service, gender). Journal Port Science Research, 2(1), 185-202. 
ournal port Science Research Available online www.jport.co Volume: 2, No:1

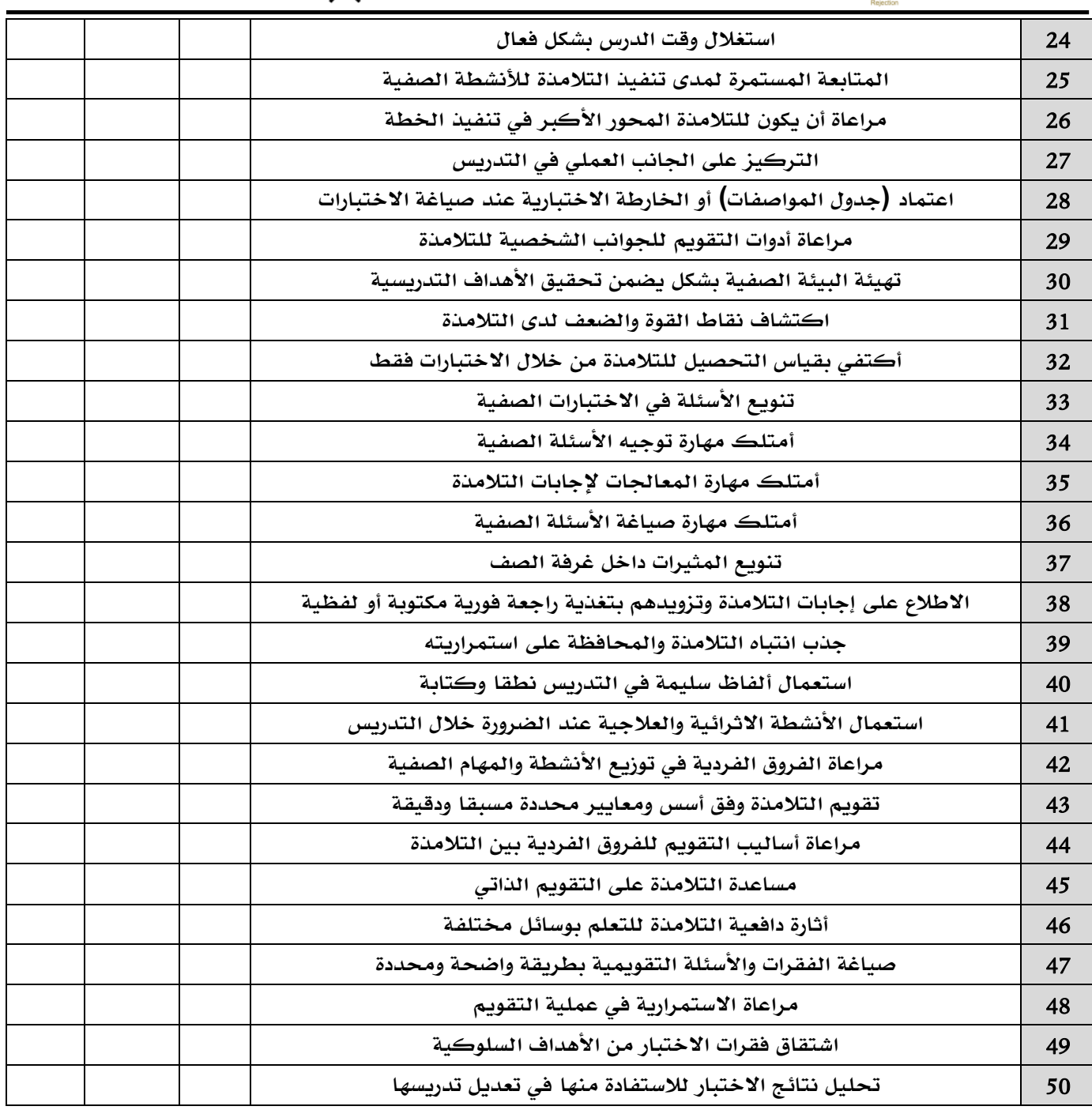

